\title{
Spatial restructuring and land consolidation of urban-rural settlement in mountainous areas based on ecological niche perspective
}

\author{
YU Zhaowu ${ }^{1}$, XIAO Lishan ${ }^{2}$, CHEN Xiji ${ }^{2}$, HE Zhichao ${ }^{3},{ }^{\text {*GUO Qinghai }}{ }^{2}$, \\ VEJRE Henrik ${ }^{1}$ \\ 1. Department of Geosciences and Natural Resource Management, Faculty of Science, University of Copen- \\ hagen, Copenhagen 1958, Denmark; \\ 2. Key Laboratory of Urban Environment and Health, Institute of Urban Environment, CAS, Xiamen 361021 , \\ Fujian, China; \\ 3. School of Geographic Sciences, Fujian Normal University, Fuzhou 350100, China
}

\begin{abstract}
With the socio-economic development associated with urbanization, the urban-rural relationship has changed across the world. In China, due to the urban-rural dual structure, these changes turn out to be more complicated. Spatial restructuring are suggested as the main strategies and spatial supporting platforms for urban-rural development. However, the theory still lacks solid methodology and support from systematic empirical studies. This study seeks an adequate scientific methodology and discusses the difference of urban-rural transformation in plains and mountainous areas. A case in Shanghang County, China, demonstrates: 1) The compound ecological niche model can be a suitable approach in urban-rural restructuring, especially in mountainous areas. 2) The urban-rural development area with highly inappropriate, slightly appropriate, moderately appropriate, and highly appropriate areas are $1273.2 \mathrm{~km}^{2}$ (44.69\%); $906.1 \mathrm{~km}^{2}(31.80 \%) ; 509.4 \mathrm{~km}^{2}(17.88 \%)$; and $160.1 \mathrm{~km}^{2}$ $(5.62 \%)$, respectively. 3 ) The "deserting villages" in mountainous areas play positive synergistic roles in urbanization, in contrast to the "hollowing villages" common in plain areas. 4) The central town-village will become the most important settlement in mountainous areas. Therefore, we suggest more attention should be paid to environmental capacity in the construction of central town-villages. This study significantly extends the understanding of "hollowing village" theory and regional planning.
\end{abstract}

Keywords: spatial restructuring; ecological niche; urban-rural settlement; deserting village; hollowing village; central town-village

\section{Introduction}

The distribution and density of urban-rural settlements relative to geo-ecological, socio-

Received: 2017-02-03 Accepted: 2017-04-18

Foundation: National Natural Science Foundation of China, No.41301621; Institute of Urban Environment, Chinese Academy of Sciences and National Scholarship Committee

Author: Yu Zhaowu (1990-), PhD Candidate, specialized in studies on urbanization and urban thermal environment effect. E-mail: zhyu@ign.ku.dk 
economic, and cultural conditions are critical factors in the general urban-rural relationship. Rural settlements will exert significant influence on regional development not only at the macro scale role but also on growth and direction (Bański and Wesołowska, 2010; Woods, 2007; Zhu et al., 2014). With industrialization and urbanization, urban-rural settlements have experienced significant changes across the world, especially in developing, newly industrialized countries (Woods, 2013). Rapid urbanization, urban-rural social transformation, and declining employment opportunities in rural areas have been major driving forces behind changes in rural areas (Chisholm, 1972; Peng et al., 2016; Tan and Li, 2013). Yet, ecologically, the land of towns and villages still remains a less familiar frontier across the world (Forman, 2016).

Since the implementation of the reform and opening-up policy in 1978, Chinese urban-rural regions have experienced a rapid and far-reaching transition and spatial restructuring process within the frames of large-scale industrialization and rapid urbanization that have lasted nearly 40 years. These processes are ongoing (Liu et al., 2010; Long, 2014; Long and Liu, 2015; Tan and Li, 2013). Similar to other regions in the world, this urban-rural restructuring is interlinked with rural decline, urban-rural spatial pattern restructuring, socio-economic transformation, and declining rural employment opportunities (Kiss, 2000; Long et al., 2016; Long and Liu, 2015; Morrill et al., 1999; Woods, 2013). These processes generally result in villages shrinking. However, the urban-rural settlement transition and development in China is different from Western developed countries. It is generally more complicated due to the urban-rural dual structure (residential registration system and land collective ownership system), as well as the deepening impact of globalization (Long and Liu, 2015). Previous studies have demonstrated that the changes vary among regions, e.g., the rural areas near cities and the rural areas in distant and mountainous areas have different development statuses (Antrop, 2004; Clark et al., 2009). In China, the latter group suffers from resource depletion, population decrease, and infrastructure deficits, because of the weak connections with cities and inadequate government policies (Long et al., 2011; Peng et al., 2016; Tan and Li, 2013).

In rural settlements in the plain areas of North China, a trend of population decline and the distinctive Chinese phenomenon of "village hollowing" result from the dual-track structure and socio-economic development of the urban-rural systems. Hollow villages can be characterized by three main phenomena: 1) a decrease in population and arable land; 2) housing abandonment (but not demolition) in the village center; and 3) settlements sprawling around the villages (Long, 2014; Long and Liu, 2015; Tan and Li, 2013). Contemporary legislations and regulations also affect this process. For instance, to better protect property rights, improve land circulation, increase farmers' incomes, and contribute to the development of modern agriculture, the State Council of China enacted land collective ownership reform on Oct. 30, 2016, to stabilize the Rural Land-Contract Relationship (official website of the Central People's Government of China: http://www.gov.cn/xinwen/2016-10/30/content_5126200.htm). Land ownership in rural land of China will be separate from Land-Use Rights, Contract Rights, and Operating Rights. The so-called "Separation of Three Rights" of land ownership means that the farmers will keep the Contract Rights of the rural land, while, in the future, Operating Rights can be traded and leased to others to operate and manage. Furthermore, farmers can use the lands for a mortgage from the financial institutions: all of this had been 
forbidden previously.

Currently, Chinese policies regarding rural settlements and urban-rural development primarily focus on rural plains and coastal areas, and lack attention to mountainous areas (Long et al., 2016; McGranahan et al., 2007). Studies about the so-called "three-wheel" driving mechanism for the evolution of rural settlements have been suggested (Zhou et al., 2013). The "increasing vs. decreasing balance" land-use policy has been adopted by the Chinese government and studied by researchers to balance increases in urban construction land with a reduction in rural construction land (Long et al., 2012). Land consolidation and urban-rural spatial restructuring as the main strategy to implement urban-rural coordinated development have been studied. Urban-rural restructuring can be measured in spatial, economic, and social dimensions, and it is usually pushed forward by rural development elements restructuring, structural optimization, and functional evolution of the rural territory system (Long, 2014; Long et al., 2016; Woods, 2013).

The concept of urban-rural spatial restructuring includes the physical evolution of rural space and optimization and adjustment of the present rural space (by means of planning, generally government-oriented) by reshaping the socio-economic structure in rural areas owing to the integrated result of endogenous development needs and exogenous driving forces (Long and Liu, 2016; Yao and Xie, 2016). Yang et al. (2016) investigated the rural spatial distribution pattern and characteristics of China and detected that economic development and tradition are main influential factors on the rural spatial pattern. The study also found that the average distance to a main roadway, agricultural machinery, per capita grain production, per capita arable land, population density, elevation, precipitation, etc. also influenced the rural spatial development and restructuring. Based on a set of methods concerning landscape security pattern construction (ant colony optimization algorithm and scenario simulation), Yao and Xie (2016) studied the rural spatial restructuring in an ecologically fragile mountainous area. Accordingly, they suggested that the methodology of the study proved to be a useful technical tool supporting rural spatial restructuring. Wang et al. (2014) established a rural residential symbiotic restructuring system using the symbiotic theory. Then they formulated productivity-oriented, service-oriented, and living-oriented residential restructuring patterns at the local scale. One of the important reasons for rural spatial restructuring is alleviating poverty and improving living standards of the rural population. A study by Lo et al. (2016) examined poverty alleviation due to resettlement, which is a key type of spatial restructuring in rural China. The study also describes the significant challenges remaining to be addressed for short-distance and long-distance resettlement, including establishing two-way communication between villagers and the government about resettlement plans and providing better financial support for the resettlers.

Previous studies paid more attention to rural living/residential spatial restructuring in rural areas (Long and Liu, 2016; Yao and Xie, 2016). However, the rural area is not just a living place, but also provides other functions (i.e., agricultural production, aesthetic, and ecological value). Therefore, the concept of rural restructuring has gradually shifted from single "living function" to a multifunction of "production, living and ecology," which is the conceptual model advanced by Liu and Long (Liu et al., 2010; Long et al., 2011). The conceptual model describes urban-rural spatial restructuring, coupling rural production, living, and ecological spatial restructuring with agricultural land consolidation, hollowed villages con- 
solidation, and industrial and mining land consolidation (Long, 2014; Long and Liu, 2016; Long et al., 2016). However, this conceptual model still lacks solid methodology and systematic empirical evidence that can build favorable rural production, living, and ecological space, and facilitate the development of urban-rural integration. Since the distribution of urban-rural settlements resembles that caused by biological behavior in the environment, the spatial restructuring and land consolidation may be thought of as filling the most appropriate niche (Han et al., 2015). Therefore, compound ecological niche analysis has been used in this study. Many publications have reported that the pattern, process, and mechanism in remote mountainous areas and plain areas are significantly different (Zhao et al., 2013a). This means the "hollowing village" phenomenon in plain areas, which has been studied and described by many researchers, may not be the same state of affairs in mountainous areas ( $\mathrm{Li}$, 2012; Yu et al., 2016; Zhou et al., 2013). Therefore, this paper aims to: 1) explore and assess the methodology of urban-rural settlement spatial restructuring based on the ecological niche model; 2) focus on the case of mountainous areas of China, which are characterized by "deserting villages" in contrast to the "hollowing villages" in plain areas; and 3) propose possible policy implications and highlight the roles of the central town-village in mountainous areas.

\section{Study area and data processing}

\subsection{Study area}

The study area is Shanghang County, located in Fujian Province (southeast China) $\left(24^{\circ} 46^{\prime} 02^{\prime \prime} \mathrm{N}-25^{\circ} 27^{\prime} 47^{\prime \prime} \mathrm{N}, 116^{\circ} 15^{\prime} 50^{\prime \prime}-116^{\circ} 56^{\prime} 47^{\prime \prime}\right)$, and covers an area of $2879 \mathrm{~km}^{2}$ (Figure 1). Shanghang County is a typical mountainous area, with vast low-altitude mountainous and hilly lands, covering $80 \%$ of the county's total. The topography of Shanghang is known as a county comprising "eighty percent of mountains, ten percent of water, and ten percent of farmland." The study area is surrounded by the Wuyi Mountains and the Bopingling Mountains and includes an important ecosystem (the core areas of the Wuyi Mountains is a UNESCO World Natural Heritage Site). At the beginning of the 21st century, Shanghang County experienced rapid socio-economic development, indicated by the increase in GDP and GDP per capita between 2004 and 2014 from 3.98 billion yuan to 22.67 billion yuan and from 8249 yuan to 61,187 yuan respectively. In the same period, the urbanization rate of Shanghang County increased from $18.6 \%$ to $42.1 \%$, and the growth rate reached $2.14 \%$ annually. Shanghang County is still in a period of rapid urbanization: a previous study based on location quotients and rurality index, identified that Shanghang County is the most dynamic area of urban-rural transformation in Fujian Province (Xiao et al., 2015).

Recently, Shanghang County's government promoted the so-called the "New Countryside" and the "New-Type Urbanization" strategies. The consequence was that the urban-rural spatial pattern, particularly the distribution of rural settlements, has changed dramatically. This process has been based on the specific geographical context, including industrialization, urbanization, and political influence; these factors together are quite typical in Fujian Province, and for the rest of China. Shanghang County therefore represents typical development features of China and the region. 


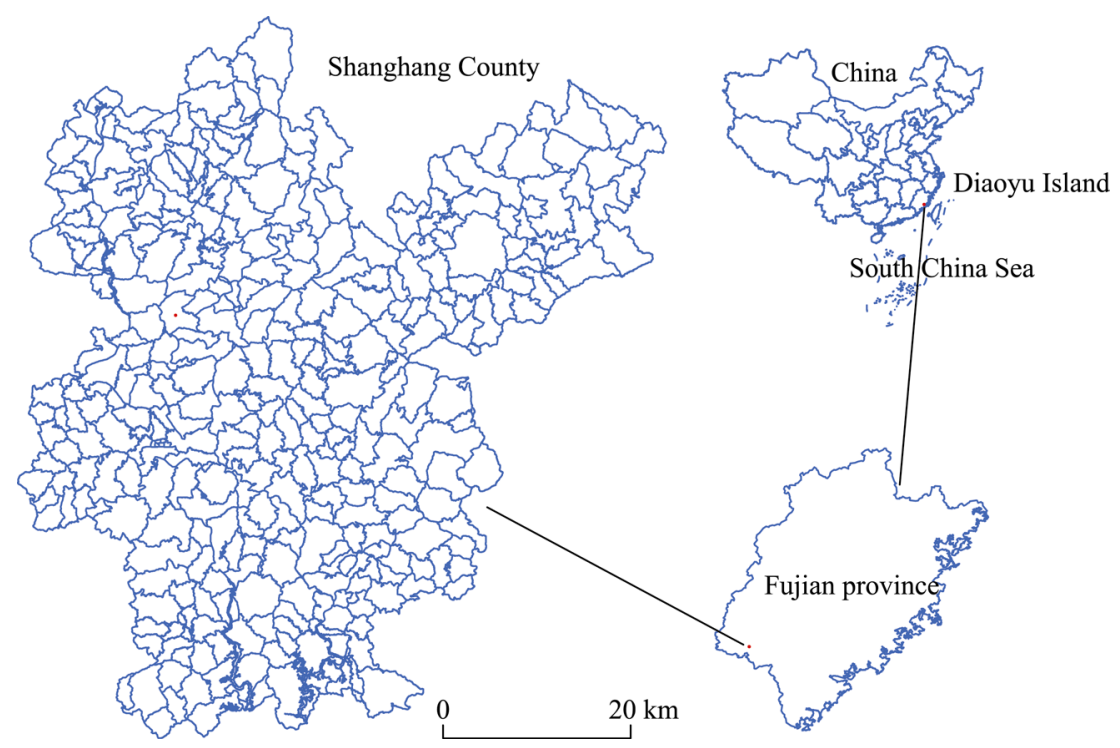

Figure 1 The study area

\subsection{Data collection and processing}

To explore urban-rural spatial restructuring based on ecological niche theory in Shanghang's case, SPOT5 (2.5 m) and Gaofen-1 (2 m) remote sensing images from 2004 and 2014, DEM (Digital Elevation Model, 1:50,000), soil, and geological hazard data in Shanghang County were used. Socio-economic data were harvested from the Statistical Yearbook (2004 and 2014), the Urban Master Planning (2013-2030), the Traffic Distribution Map (2014), and other related data in Shanghang County.

Firstly, ERDAS9.2 software was used to conduct image registration, geometric correction (WGS 1984), and image mosaic. Secondly, artificial visual interpretation was used to assess the distribution of urban-rural settlements. We extracted 1249 and 812 urban-rural settlements in 2004 and 2014, respectively. To ensure the accuracy of interpretation, we used Google Earth images ( $0.6 \mathrm{~m}$ resolution) to verify the completed data. The similarity in 2014 was $96 \%$. (Due to the lack of high-resolution historical imagery of Shanghang County in Google Earth in 2004, we did not check for that year.) Further, we randomly selected 25 patches for field validation. Twenty-three of these rural settlements were identified (92\%). Subsequently, we plotted a vector map of the urban-rural settlement spatial distribution of Shanghang County. Geographic data and socio-economic data were uploaded to ArcGIS 10.3 to create a vectorization of the initial database with natural socio-economic attributes.

\section{Methodology}

\subsection{Compound ecological niche model}

Johnson proposed the concept of the ecological niche in 1910, arguing that the different species in the same area occupy different niches in the environment (Liu and Ma, 1990). Hutchinson (1958) argued that the environmental factors affecting a species could be conceived of as a set of $n$ coordinates. For each of these coordinates, a limiting value exists, within 
which the species can survive and reproduce. The ranges of the coordinates within the limiting values define an $n$-dimensional hypervolumes, at any point within which resources and environmental conditions would permit the species to exist indefinitely. Johnson proposed the concepts of the "foundational niche" and the "realized niche" (Cao, 1995; Hairston et al., 1960; Whittaker et al., 1973). Odum (1983) proposed the general concept of the "ecological niche," which refers to the location and condition of a species' shape adaptation, physiological responses, and peculiar behavior (Zhang and Xie, 1997). In this context, it is assumed that the distribution of urban-rural settlements resembles that of natural ecological behavior in the environment. Hence, an urban-rural settlement could be viewed as a nature-economy-society, occupying a specific complex ecosystem niche, as suggested by Zhao et al. (2013b) from the perspective of the household registration system, land ownership, and land-use regime.

The process of the urban-rural settlement spatial restructuring should focus on identifying the most appropriate distribution pattern of settlements. Urban-rural spatial restructuring demands a combination of various factors, which constitute the $n$-dimensional space of the region. However, each factor has a threshold value, which implies that the ecological niche fitness will change if the threshold value is exceeded, i.e., a slope of agriculture land greater than 15 degrees is not suitable for cultivation. When the regional resources and environment can fully satisfy the demands of urban-rural settlement distribution, then the ecological niche fitness is equal to 1 . If the converse is true, the ecological niche fitness is equal to 0 (Han et al., 2015; Nie et al., 2012; Qu et al., 2010; Li and Lin, 1997).

In this study, the compound ecological niche fitness is an expression that comprises ecological factors, production factors, and living factors, which are related to the theory of how to restructure rural production, living, and ecological spaces as described above (Long, 2014; Long, 2012; Yang et al., 2016). For this purpose, we established an evaluation index system (Qin et al., 2012; Zhao et al., 2013a). The procedure is as follows: 1) A principal component analysis (PCA) method is used to determine the evaluation factors. Subsequently, the index system is constructed, achieving the index value, forming the "realized niche" structure (Table 1). The weight of indices is based on a previous study and the Delphi method (Qin et al.,

Table 1 Suitability evaluation indicators and "realized" value in Shanghang County

\begin{tabular}{|c|c|c|c|c|c|c|}
\hline \multirow{2}{*}{\multicolumn{2}{|c|}{ Evaluation indicators }} & \multirow{2}{*}{ Index properties } & \multicolumn{2}{|c|}{ Realized index value } & \multirow{2}{*}{ Weight } & \multirow{2}{*}{$\begin{array}{c}\text { Total } \\
\text { weight }\end{array}$} \\
\hline & & & Range & Mean value & & \\
\hline \multirow{4}{*}{$\begin{array}{l}\text { Ecological } \\
\text { factors }\end{array}$} & $X_{1}$ & Continuity, has boundary conditions & $0-2.96$ & 1.37 & 0.153 & \multirow{4}{*}{0.441} \\
\hline & $X_{2}$ & Conceptual, no boundary conditions & - & - & 0.088 & \\
\hline & $X_{3}$ & Conceptual, no boundary conditions & - & - & 0.107 & \\
\hline & $X_{4}$ & Conceptual, has boundary conditions & - & - & 0.093 & \\
\hline \multirow{3}{*}{$\begin{array}{l}\text { Living } \\
\text { factors }\end{array}$} & $X_{5}$ & Continuity, no boundary conditions & $0-0.026$ & 0.0013 & 0.115 & \multirow{3}{*}{0.354} \\
\hline & $X_{6}$ & Continuity, no boundary conditions & $0.48-8.55$ & 3.71 & 0.123 & \\
\hline & $X_{7}$ & Continuity, no boundary conditions & $0-9.90$ & 0.99 & 0.116 & \\
\hline \multirow{2}{*}{$\begin{array}{l}\text { Production } \\
\text { factors }\end{array}$} & $X_{8} / \mathrm{km}$ & Continuity, has boundary conditions & $0-14.46$ & 2.83 & 0.099 & \multirow{2}{*}{0.205} \\
\hline & $X_{9}$ & Continuity, no boundary conditions & $0-202.81$ & 185.16 & 0.106 & \\
\hline
\end{tabular}

Annotation: $X_{1}$ : terrain niche; $X_{2}$ : aspect of slope; $X_{3}$ : soil erosion and geological disasters; $X_{4}$ : ecological function zone; $X_{5}$ : scale of town-village; $X_{6}$ : accessibility of central town-village; $X_{7}$ : road accessibility; $X_{8}$ : impact of watershed; $X_{9}$ : per capita arable land area and quality. 
2012). 2) Quantitative analysis of the land demand of the urban-rural settlement niche with restrictive conditions is performed. 3) Using the integrated ecological niche fitness model, the $n$-dimensional space assembly of urban-rural settlement is calculated. 4) By establishing the compound ecological model, the urban-rural settlement spatial restructuring is analyzed. In addition, for a spatial continuity indicator, the standard deviation and exponential model is used to estimate suitability, such as the terrain niche and the accessibility of the central town-village. For a conceptual variable, we use an assignment expression, aspect of slope, for example.

\subsubsection{Terrain niche}

The terrain is the most crucial factor in urban-rural settlement spatial distribution and construction in mountainous areas (Chisholm, 1972; Mubareka et al., 2008). The terrain niche synthesizes the elevation and slope, and it reflects the terrain factor comprehensively (Qu et al., 2010; Wang et al., 2013). By extracting the relevant DEM data, equation (1) was used to establish the terrain niche distribution map.

$$
T=\log \left[\left(\frac{E}{\bar{E}}+1\right) \times\left(\frac{S}{\bar{S}}+1\right)\right]
$$

where $T$ is the terrain niche index; $E$ is the raster elevation value; $\bar{E}$ is the average elevation value; $S$ and $\bar{S}$ represent raster slope value and the average slope value, respectively. In Shanghang County, the elevation range is $110-1807 \mathrm{~m}$, the slope value range is $0-64.55^{\circ}$. The calculated terrain niche index range is 0-2.96. Generally, the urban-rural construction suitability is negatively related to the altitude and terrain steepness. As in the National Standards of Constructing Land and our previous study (Yu et al., 2016), we set $1000 \mathrm{~m}$ and $10^{\circ}$ as the restrictive conditions in urban-rural construction and employed the piecewise function (2) to quantify the terrain niche fitness value (Figure $2 a$ ).

$$
Y_{2}=\left\{\begin{array}{l}
0, x_{2 i} \geqslant 1.49 \\
\frac{1.49-x_{2 i}}{1.59-x_{2 \min }}, x_{2 i}<1.49
\end{array}\right.
$$

where $Y_{2}$ is the value of terrain niche fitness; $x_{2 i}$ is the terrain niche, $x_{2 i \text { min }}$ is the minimum value of the realistic terrain niche; and 1.49 is the threshold value of the terrain niche.

\subsubsection{Aspect of slope niche}

The aspect of slope reflects the impact of sunlight on the distribution of the settlements. In the Northern Hemisphere, facing south is common due to better access to sunshine. Particularly, in China, "Facing South" architectural thinking has an enormous impact on urban-rural construction and layout. The fitness value of layout construction decreases from south facing slopes to north facing slopes, i.e., from sunny to shady. We extracted the aspect of slope profiles from the DEM data, and then used the assignment expression to calculate the fitness value (Figure $2 b$ ).

\subsubsection{Soil erosion and geological disaster niche}

Soil erosion and geological disaster are supposed to be one of the most important niches in 
urban-rural distribution in mountainous areas (Hewitt, 2014; Molden et al., 2015; Zhao et al., 2013a). The types of geographical hazard in Shanghang County include debris flows, collapses, and landslides. The Geographical Hazards Detailed Profile in Shanghang County 2011, the Grade Distribution of Geological Disasters in Shanghang County, and the Soil Erosion Map in Shanghang County were all consulted. Finally, we calculated the soil and geographical disaster fitness value (Tables 3-4 and Figure 2c).

\subsubsection{Ecological function zone niche}

The key ecological function zone (such as national nature reserve) has important ecological value. Mountains are one of the richest regions of biological diversity, which means the urban-rural settlement optimal adjustment must consider important ecological functions (Sevenant and Antrop, 2007; Zhao et al., 2013a). Based on the National Nature Reserve Planning, the Nature Reserve Planning of Shanghang County, and the Ecological County Planning, the ecological function level distribution map of Shanghang County was calculated (Figure 2d).

\subsubsection{Scale of urban-rural niche}

The size of a settlement is an important niche of urban-rural development. The population density and land-use allocation affect the potential and the direction of urban-rural settlement (Chisholm, 1972; Morrill et al., 1999; Wu, 2002). According to the land use pattern of each administrative village in Shanghang County and China's Sixth Nationwide Population Census. We extracted the land-use and population data, using function (3) to analyze the fitness value.

$$
Y_{3}=\frac{x_{3 \max }-x_{3 i}}{x_{3 \max }-x_{3 \min }}
$$

where $Y_{3}$ is the value of the scale of urban-rural niche fitness; $x_{3 i}$ is realized ecological niches of the scale of the urban-rural settlement, $x_{3 \max }$ and $x_{3 \min }$ is the maximum and minimum value of the realized ecological niches. Finally, we obtain the results shown in Figure $3 a$.

\subsubsection{Accessibility of central town-village niche}

Central town-villages experienced the most dramatic change in the process of rapid mountainous urbanization, and the population and public infrastructure gradually moving to this area (Zhang et al., 2015). Therefore, the accessibility of the central town-villages is very important to niche appropriateness. The so-called Two-step Floating Catchment Area Method (2SFCA) is a special version of the gravitation model. One of its assumptions is that the accessibility in a certain search radius is equal, yet it does not match with the law of diminishing with distance (Luo and Whippo, 2012). Hence, Dai (2011) proposed the Gaussian-based 2SFCA, which is what we used.

The stepwise procedure for this calculation is as follows:

Step 1: for each central town-village location $j$, all town-village locations $k$ that are within a threshold distance from $j$ are searched. The ratio $\left(R_{i}\right)$ of the central town-village to the town-villages is written as: 


$$
R_{j}=\frac{s_{j}}{\sum_{k \in\left\{d_{k j} ; \leqslant d_{0}\right\}} G\left(d_{k j}, d_{0}\right) D_{k}}
$$

where $d_{k j}$ is the distance between $j$ and $k ; D_{k}$ is the number at location $k$ whose centroid falls into the catchment from central town-village location $j ; S_{j}$ is the capacity of central town-village at $j$; and $G$ is the friction of distance listed below:

$$
G\left(d_{k j}, d_{0}\right)=\left\{\begin{array}{l}
\frac{e^{-(1 / 2) \times\left(d_{k} / d_{0}\right)^{2}}-e^{1(1 / 2)}}{1-e^{-(1 / 2)}}, d_{k j} \leqslant d_{0} \\
0, d_{k j}>d_{0}
\end{array}\right.
$$

Step 2: for each town-village location $i$, all central town-villages $j$ within the threshold $d_{0}$ from $i$, were searched, thus summing up the supply and demand ratio $\left(R_{j}\right)$ of the town-village to obtain the town-village's location $i$ and spatial accessibility $A_{i}^{F}$, as follows:

$$
A_{i}^{F}=\sum_{j \in\left\{d_{i j} \leqslant d_{0}\right\}} R_{j}=\sum_{j \in\left\{d_{i j} \leqslant d_{0}\right\}} \frac{S_{j}}{\sum_{k \in\left\{d_{k j} \leqslant d_{0}\right\}} G\left(d_{k j}, d_{0}\right) D_{k}}
$$

where $d_{i j}$ is the distance between $i$ and $j ; R_{j}$ is the supply and demand ratio within the town-village centroid $i$. The value of $A_{i}^{F}$ is positively related to accessibility (Figure 3b).

\subsubsection{Road accessibility niche}

Road conditions had a significant impact on the spatial evolution and restructuring of rural settlements experiencing rapid urbanization. Settlements increasingly gathered near transit lines and central town-village along with the improving of road accessibility condition (Liu et al., 2009; Ren et al., 2014). We used a traffic distribution map to conduct a buffer analysis, and the equation created by Qin et al. (2012) was used to calculate the road accessibility niche fitness, as Figure 3c shows.

\subsubsection{Impact of watershed niche}

The watershed provides the basic conditions for human survival: the distribution and location of human settlements begins with the accessibility to fresh water. Generally, closer to the watershed, the residents would have better production and living conditions, so more residents would live near the watershed. We use equation (7) to quantify this as follows (Figure 4a):

$$
Y_{8}=\frac{x_{8 \max }-x_{8 i}}{x_{8 \max }-x_{8 \min }}
$$

where $Y_{8}$ is the value of effect of watershed niche fitness; $x_{8 i}$ is the realized ecological niche of the watershed buffer zone, $x_{8 \max }$ and $x_{8 \min }$ are the maximum and minimum values of realized ecological niches of the watershed buffer zone.

3.1.9 Per capita arable land area and quality niche

A certain amount of the lands suitable for farming is a prerequisite for the location of urban-rural settlements, particularly in mountainous areas. Per capita arable land area and 
quality has a significant influence on agricultural production and quality of living, and affects urban-rural development (Chisholm, 1972; Unwin and Nash, 1992).

Arable land quality includes soil organic matter (SOM), the effective thickness of the soil layer, and the probability of irrigation, soil texture, soil structure, and terrain slope. Soil quality grading standards were based on the fitness of staple crop growth, then using the Delphi method to determine the weights, and quantifying the land quality by the standard deviation (Qu et al., 2010):

$$
\begin{gathered}
Y_{9}=\frac{\left|x_{9 i}-x_{9 a i}\right|}{S_{9 i}} \\
S_{9 i}=\sqrt{\frac{1}{m} \sum_{i=1}^{m}\left(x_{9 i}-x_{9 a i}\right)^{2}}
\end{gathered}
$$

where $Y_{9}$ is the value of arable land quality niche fitness, $x_{9 i}$ is realized ecological niche of arable land quality, $x_{9 a i}$ is the mean value of realized ecological niche of arable land quality, $S_{9 i}$ is the standard deviation of realized ecological niche of arable land quality, and $m$ is the number of raster (Figure 4b).

\subsection{The urban-rural settlement compound ecological niche fitness}

Shelford's law of tolerance suggests that the success of the organisms is based on a complex set of conditions (Shelford, 1931; Webber et al., 2012). When the current regional conditions in the quantity or quality of urban-rural settlements are close to the threshold, this is the limiting factor. This could be, e.g., a core area of a national nature reserve. The data are normalized and weighted, then we calculate the compound ecological niche fitness value (10) (Qu et al., 2010):

$$
\begin{cases}x_{n}=0 & x_{i j}=0 \\ x_{n}=\sum_{i=1}^{n} x_{i j} \times w_{i} & x_{i j} \neq 0\end{cases}
$$

where $X_{n}$ is the urban-rural settlement compound ecological niche fitness, $i$ is the index ecological niche fitness in each grid cell, $w_{i}$ is the weights of $i$ index, and $n$ is the number of the evaluation index.

\section{Results}

\subsection{Evaluating results of the ecological niches of the urban-rural settlements}

\subsubsection{Ecological factors}

The highest values of terrain niche fitness were identified in the west of the county, and characterize a distribution pattern along the Tingjiang River from north to south (Figure 2a). However, the results indicate that Shanghang County has low terrain niche fitness. Highly inappropriate areas accounted for $49.11 \%$ of the county's area and highly appropriate areas for just $9.53 \%$.

Based on the DEM data, we extracted aspect of slope information (Figure $2 \mathrm{~b}$ and Table 2). The high fitness value (fitness value $\geqslant 0.75$ ) and low fitness value (fitness value $\leqslant 0.25$ ) of 
the aspect of slope were $64.05 \%$ and $12.02 \%$, respectively.

The results show that highly sensitive areas in terms of the soil erosion and high risk of geological disasters (fitness value $\leqslant 0.5$ ) are $68.30 \%$ and $67.89 \%$ of the area, respectively (Tables 3 and 4). Overlay analysis revealed that the combination of low soil erosion and low geological disaster only account for $10.27 \%$ of the area (Figure $2 \mathrm{c}$ ). This means that the suitable areas for development of urban-rural settlements in Shanghang County are limited. It also indicates that in the urban-rural settlement development and urbanization process, more attention should be paid to soil and water conservation, as well as the impacts of geological disasters.

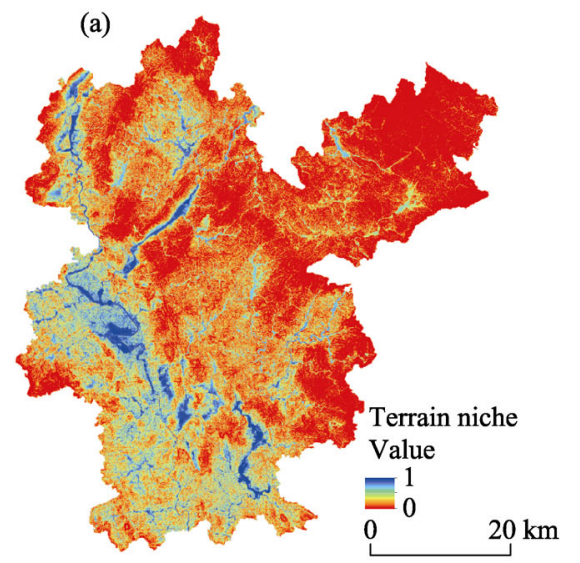

(c)

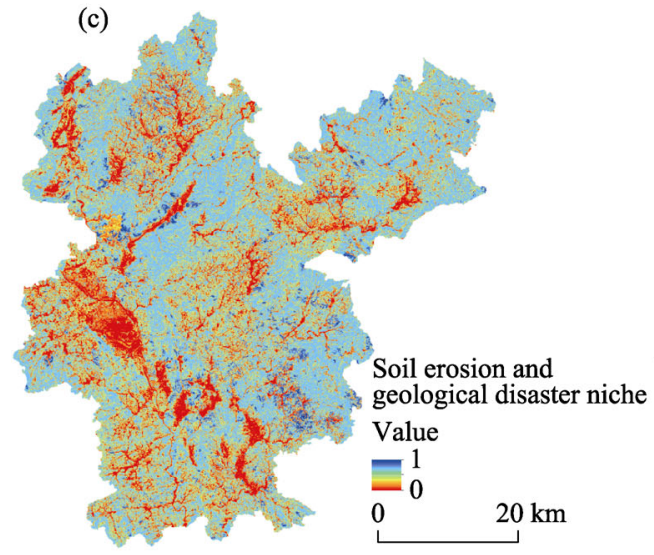

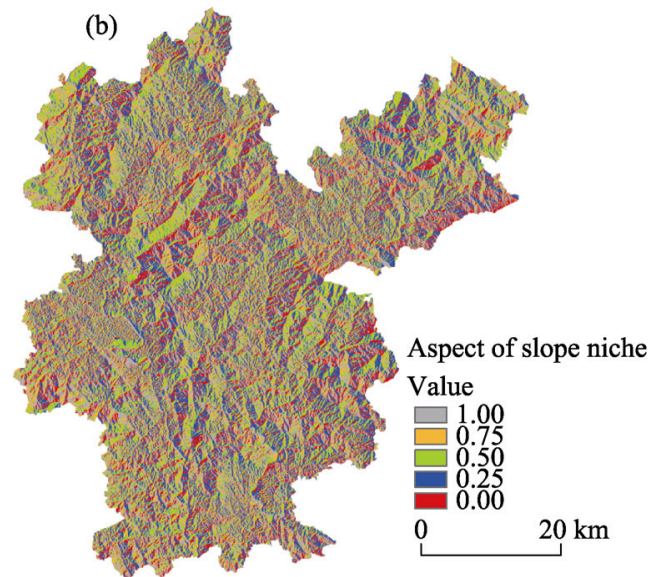

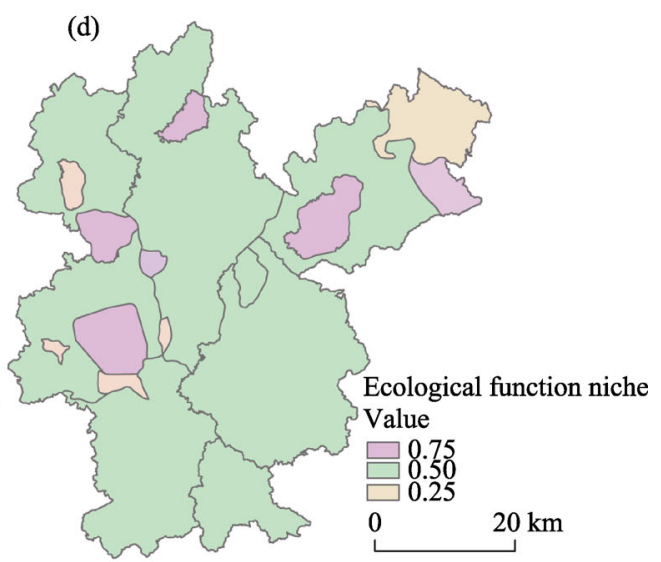

Figure 2 The fitness value results of the ecological factors

Table 2 The quantitative results of the aspect of slope

\begin{tabular}{lcclcc}
\hline Aspect & Area proportion (\%) & Fitness value & Aspect & Area proportion (\%) & Fitness value \\
\hline Horizontal & 0.19 & 1.00 & South & 12.76 & 1.00 \\
North & 5.97 & 0.25 & Southwest & 12.57 & 1.00 \\
Northeast & 11.80 & 0.50 & West & 13.37 & 0.75 \\
East & 12.76 & 0.75 & Northwest & 12.11 & 0.50 \\
Southeast & 12.40 & 1.00 & North & 6.05 & 0.00 \\
\hline
\end{tabular}


Table 3 Soil erosion level quantitative indicator

\begin{tabular}{lccc}
\hline Soil erosion sensitive level & Area $\left(\mathrm{km}^{2}\right)$ & Area proportion $(\%)$ & Fitness value \\
\hline Highly sensitive & 41.81 & 1.46 & 0.00 \\
Moderately sensitive & 1907.93 & 66.84 & 0.25 \\
Slightly sensitive & 718.03 & 25.15 & 0.50 \\
General sensitive & 187.02 & 6.55 & 0.75 \\
\hline
\end{tabular}

Table 4 Geological disasters level quantitative indicator

\begin{tabular}{lccc}
\hline Geological disasters level & Area $\left(\mathrm{km}^{2}\right)$ & Area proportion $(\%)$ & Fitness value \\
\hline Low risk area & 924.33 & 32.11 & 0.75 \\
Moderate risk area & 1600.81 & 55.60 & 0.50 \\
High risk area & 353.86 & 12.29 & 0.25 \\
\hline
\end{tabular}

We divided Shanghang County into three kinds of areas: key ecological functional protected areas (including the core area of the national nature reserve and key water resources), general ecological functional protected areas (including agro-ecology, watershed landscapes, and eco-tourism areas), and towns and mining areas (including urban areas, town and mining areas) (Figure 2d).

\subsubsection{Living factors}

The size of the urban-rural settlement results shows that the most suitable area for living was the county town (county seat) and its surrounding suburban areas, followed by the areas where the township government is located. Other regions' fitness values were significant lower (Figure 3a). Therefore, from the size of the urban-rural settlements, the urban-rural spatial restructuring and optimal control should emphasize on the central town-villages, where is the location of township government, as a support point.

Based on the 2SFCA model, high-accessibility central town-villages were primarily in the center and northeast of Shanghang County, whereas low accessibility was in the south and northwest (Figure 3b). Specifically, the high fitness value of accessibility, moderate fitness value of accessibility, low fitness value of accessibility, and extreme unfitness value of accessibility were $17.53 \%, 20.39 \%, 21.37 \%$, and $40.71 \%$ of the area, respectively.

Road accessibility niche fitness indicates that the moderately appropriate, the highly appropriate, and highly inappropriate areas for road accessibility were $65.96 \%, 14.65 \%$, and $19.39 \%$, respectively (Figure 3c), which means that Shanghang County already has a relatively good transportation network.

\subsubsection{Production factors}

The grid computing results indicated that the high value of the impact of watershed niche fitness accounts for $69.63 \%$ of the area (Figure 4a). This means that Shanghang County is a good location for human settlements development from the water supply perspective. The high/low value of per capita arable land quality niche fitness is $9.91 \%$ and $90.09 \%$, which means that Shanghang County has not enough high-quality land space for agricultural production (Figure 4b). 

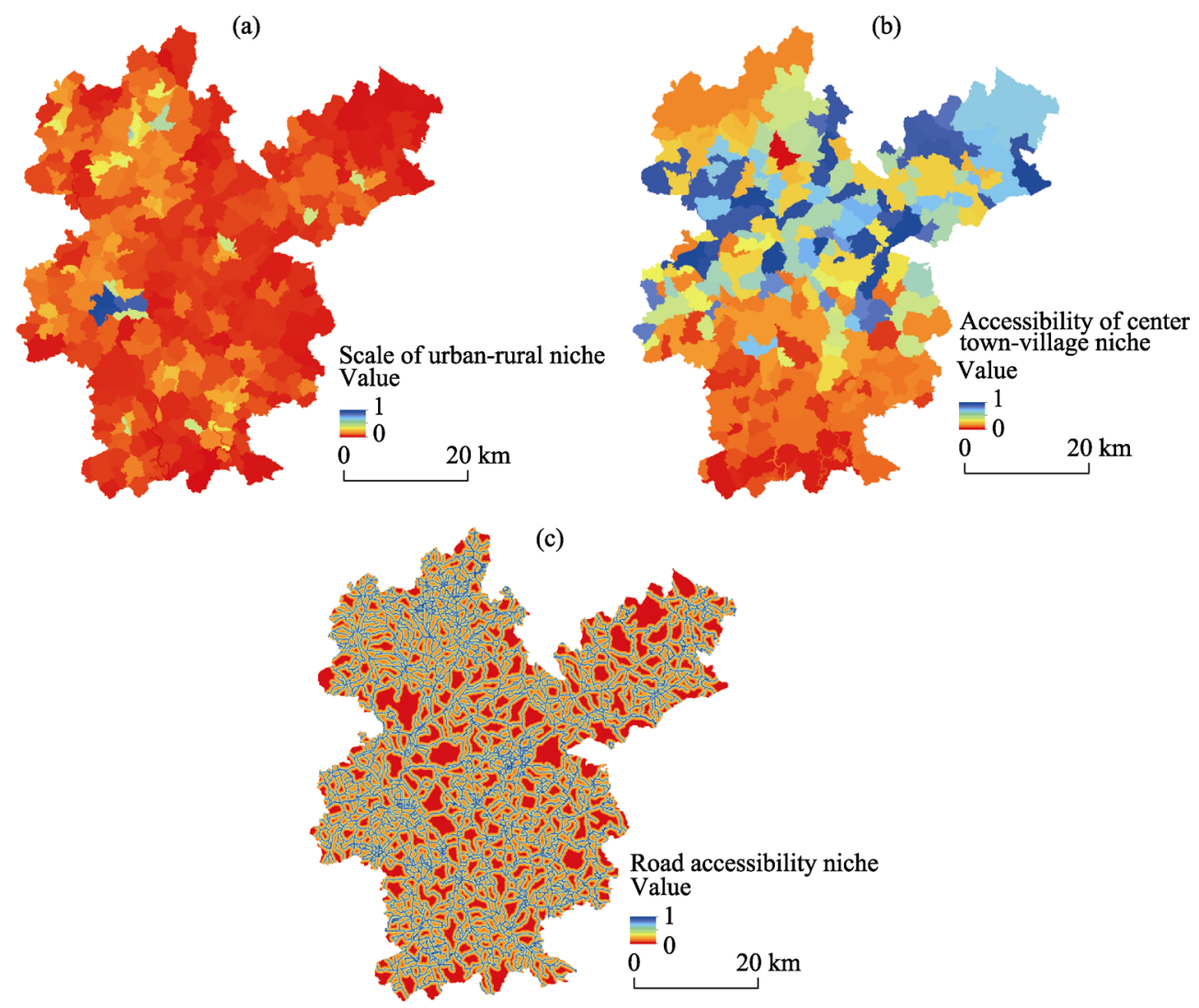

Figure 3 The fitness value results of the living factors
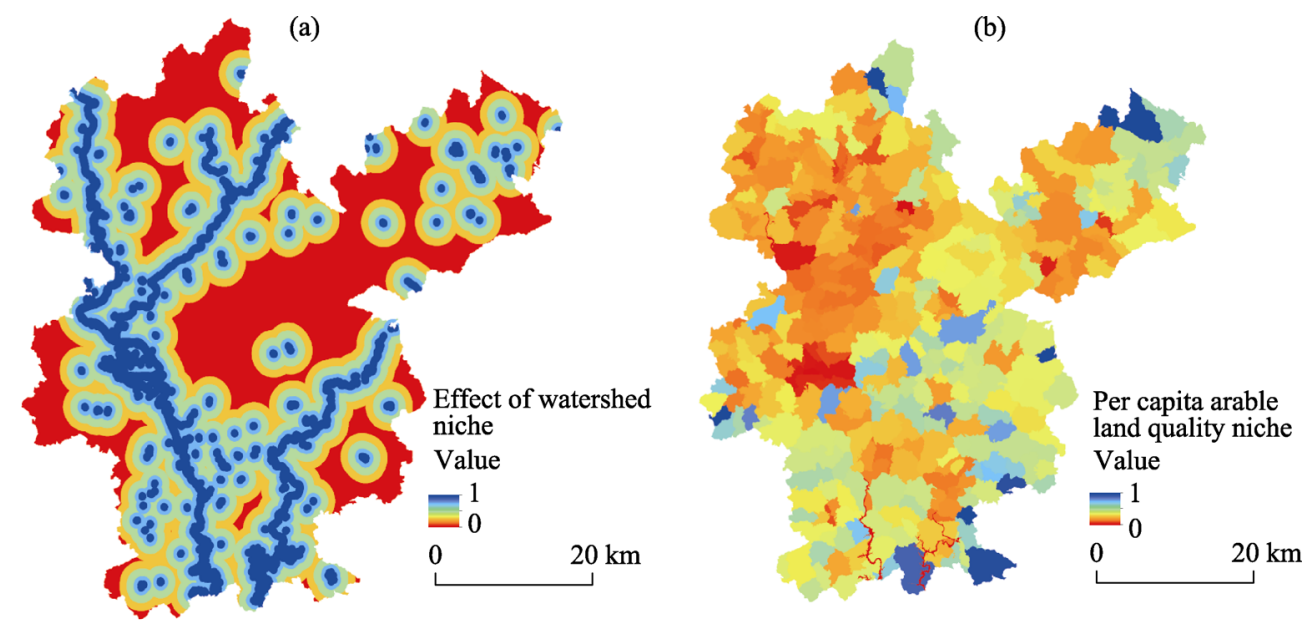

Figure 4 The fitness value results of the production factors

\subsection{General evaluation of urban-rural settlements fitness value and spatial restruc- turing}

The results revealed that the areas with a high value of fitness in Shanghang County are located in the central and northeastern parts, as well as in the river valleys (Figure 5). Specifically, the highly inappropriate, the slightly appropriate, the moderately appropriate, and the 
highly appropriate areas for urban-rural settlement construction in Shanghang County were $1273.2 \mathrm{~km}^{2}$ (44.69\%), $906.1 \mathrm{~km}^{2}$ (31.80\%), $509.4 \mathrm{~km}^{2}(17.88 \%)$, and $160.1 \mathrm{~km}^{2}(5.62 \%)$, respectively. $76.5 \%$ of Shanghang County was not suitable for urban-rural settlements, making only $23.5 \%$ suitable.

According to the results of the suitability evaluation, we identified four types of spatial restructuring mode with the identity tool in ArcGIS 10.3 and cluster analysis, as well as landscape analysis. We divided the spatial restructuring and land consolidation into four types, which were the priority development, moderate development, limited development, and migrate-regulate areas. The area percentages of the four types of urban-rural settlements were $15.52 \%, 23.15 \%, 44.70 \%$, and $16.63 \%$, respectively. $61.33 \%$ of the settlements and $20.58 \%$ of the area of settlements still need to be regulated (Table 5).

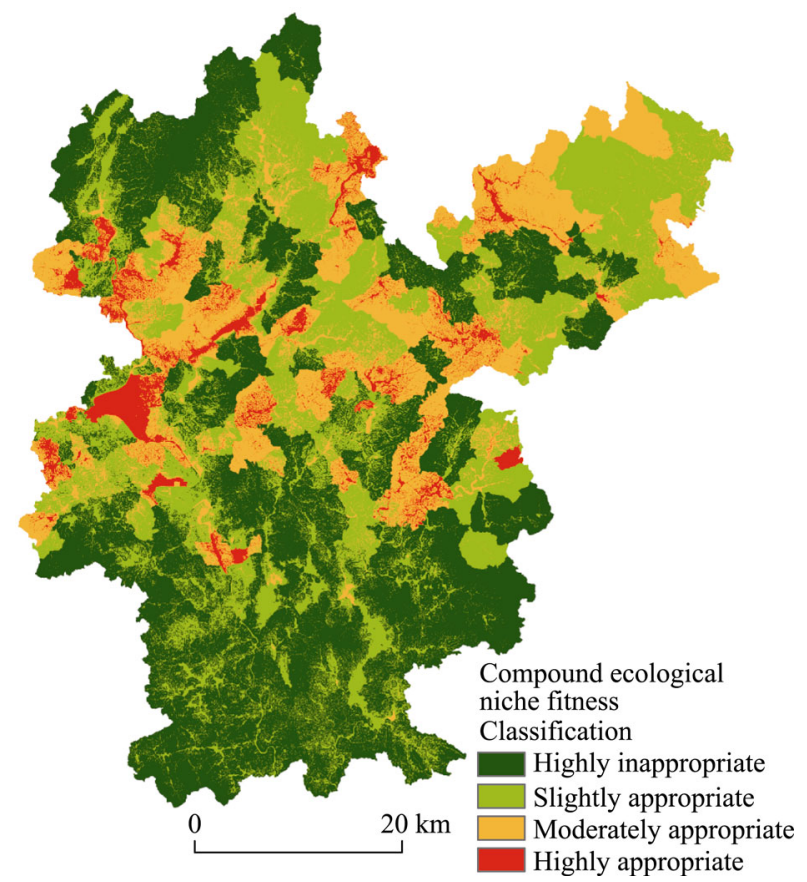

Figure 5 Classification of the urban-rural settlement lands suitability evaluation

Table 5 The statistics of four type's spatial restructuring area in Shanghang County

\begin{tabular}{lccccccc}
\hline \multicolumn{1}{c}{ Types } & $\begin{array}{c}\text { Number } \\
\text { of set- } \\
\text { tlement }\end{array}$ & $\begin{array}{c}\text { Percentage } \\
\text { of number } \\
(\%)\end{array}$ & $\begin{array}{c}\text { Area of } \\
\text { settlement } \\
\left(\mathrm{hm}^{2}\right)\end{array}$ & $\begin{array}{c}\text { Percentage } \\
\text { of area (\%) }\end{array}$ & $\begin{array}{c}\text { Mean area of } \\
\text { settlement } \\
\left(\mathrm{hm}^{2}\right)\end{array}$ & $\begin{array}{c}\text { Shape } \\
\text { index }\end{array}$ & $\begin{array}{c}\text { AWMPFD } \\
\text { Priority development area }\end{array}$ \\
\hline Moderate development area & 126 & 15.52 & 1290.07 & 14.04 & 10.24 & 1.06 & 1.04 \\
Limited development area & 363 & 44.70 & 1309.46 & 14.25 & 3.61 & 1.31 & 1.12 \\
Migrate-regulate area & 135 & 16.63 & 518.60 & 6.33 & 4.31 & 1.57 & 1.22 \\
\hline
\end{tabular}

For the urban-rural spatial restructuring of Shanghang County on a strategic level, based on our previous analysis, we proposed the "Arrow-type" spatial restructuring and development strategy (Appendix 1). On a tactical level, advanced four types of spatial restructuring according to evaluation result, and other related studies about this county (Yu et al., 2016). 
We estimate that the rural areas in Shanghang County will turn into deserting villages, central town-villages (where the township government is located), and city-oriented villages. Over a long period of time, the urban-rural spatial restructuring in Shanghang County should follow these trends and patterns.

\section{Discussion}

\subsection{Ecological niche theory has significance for urban-rural spatial restructuring}

The concept of the ecological niche describes how an organism or population responds to the distribution of resources and competitors, and how this pattern, in turn, alters those same factors. A species' niche includes all of its interactions with the biotic and abiotic factors of its environment (Odum, 1983; Whittaker et al., 1973). Normally, ecological niche theory is employed in ecology and is rarely used for urban-rural spatial restructuring and land consolidation. The human settlement also has a niche, which is affected by natural and socioeconomic conditions, hence we can regard the urban-rural settlement as occupying a natural-socio-economic complex ecosystem niche (Zhao et al., 2013a). Currently, with the continuing development of industrialization and urbanization in China, Long and Liu are developing the concept of land consolidation and urban-rural spatial restructuring from the perspectives of production, living, and ecological space, which are a new platform and major tool to implement "new-type urbanization" strategies and the agricultural modernization (Liu et al., 2013; Long, 2014; Long et al., 2016). However, a solid methodology has not yet been developed to conduct empirical case studies to verify the conceptualization of the model. Many publications focus on one or two aspects of the natural, economic, or social conditions of urban-rural reconstruction, and it is challenging to reveal the holistic reality in a comprehensive manner (Tan and Li, 2013; Zhang et al., 2015). Zhao et al. (2013a) used the Maximum Entropy Method, which integrates climate, remote sensing, and geographical data to model the distributions of human settlements and assess the land suitability for transition areas. Yao and Xie. (2016) suggested that ant colony optimization algorithms and scenario simulations could be a good way to support rural spatial restructuring. Therefore, in our study, we extracted the $n$-dimensional hypervolumes after principal component analysis, including the ecological, living, and production factors, covering the natural frame conditions and socio-economic development conditions. Then the compound ecological model was built to analyze the potential areas of urban-rural spatial restructuring, and the results showed that ecological niche theory could be used as a valuable methodology for urban-rural spatial restructuring and land consolidation from production, living, and ecological data, particularly in mountainous areas with important ecological value.

\subsection{Deserting villages in mountainous areas are different from hollowing villages in plain areas}

The "hollowing village" is a distinctly Chinese urbanization phenomenon, associated with the general evolution process of rural settlements subject to urban-rural transformation. It refers to China's residential registration system (hukou) and the collective land ownership system. It strongly affects the urban-rural landscape and rural residential land use, and it is more widespread in plain areas (Liu et al., 2010; Long and Liu, 2015). In the plain areas of 
North China, hollowing villages normally imply the disordered sprawling around a village, the abandonment - but not demolishment — of the center of the village, and the occupation of the fertile land, implying a food production crisis. The process of hollowing is disadvantageous for the coordination of rural-urban development, e.g., from the perspective of farmland change. About $60 \%$ of the residential land in rural areas was converted from former farmland in China, and more than $92 \%$ of the increased rural residential land was from farmland in the economically developed regions of coastal China (Deng et al., 2015; Liu et al., 2013; Long and Liu, 2015). However, in mountainous areas, as in our study, the situation is not the same. The situation happens in mountainous areas could be characterized as the "deserting village." Both hollowing villages and deserting villages have the same driving forces and mechanisms, which includes cultural-socio-economic, institutional, managerial, and environmental factors (Long et al., 2012). However, these driving forces resulting in different characteristics and outcomes, and present positive synergies in mountainous areas. From the perspective of geography and spatial structure, in contrast to hollowing villages in plain areas, deserting villages are normally characterized by: 1) being located in a remote mountainous region; 2) housing abandonment and demolishment in the village (housing in the center of a deserting village is not just abandoned, but also demolished); 3) many small size settlements with scattered pattern (the spatial pattern of the deserting village is not like the hollowing village, which is urban sprawling around the hollowing village). In addition, the deserting villages are often characterized by the high biological values and hence often ecological sensitive areas. From the perspective of socio-economic features, the deserting village comprises demographic decline and demise, arable land and housing deserted, public-investment drop and lower income compare to the central town-village and cities. This trend is harder to reverse compare to the hollowing village, which is a significant difference between the spatial restructuring of the hollowing village and the deserting village, as well as the big challenge for the deserting village.

Specifically, the deserting village in mountainous areas means the residents always choose to move to the central town-villages (cities) to seek a better living condition based on interview and questionnaire surveys with the residents and the local authorities. The results showed that, in the remote and deserting village, because of the poor traffic conditions, low job and income levels, most of the young people perennially work and live in the central town-villages and cities. This results in the depopulation and demise of the villages and reduction of the will for public infrastructure investment. Besides, different from living in the big cities, the village residents live in the central town-village can reach equilibrium between being engaged in agricultural and forestry production and convenient access to the public services. One pilot study informed that more than $90 \%$ of the local authorities argue that the public investment could be reduced in the future to balance the trade-off and ecological conservation policy (Yu et al., 2016), e.g., to achieve the target of the National Spatial Development Pattern of China. In Fujian Province, 34 counties (including Shanghang County) account for $40.5 \%$ of the province's total, carried out the performance evaluation of ecological conservation priority mode rather the GDP development and assess oriented.

Additionally, differs from the hollowing village, as the rural depopulation continues, more and more disused housing lands appears in rural communities and left unchecked villages can fall into 'vanishing degeneration'. But the deserting village in mountainous areas could be a positive trend not just for the ecological conservation but also for the improvement of 
living conditions for the local residents because of this natural socio-economic process that the residents who live in remote village moving to the central town-village or small city could improve the living standard and more access to the public services. Thus, this process is positive synergies in mountainous urbanization, or it can be called 'vanishing evolution'. Hence, when we describe village shrinking, the critical aspect of understanding of 'hollowing village' and 'deserting village' is that two of this have a different meaning in the urbanization process of China. Furthermore, the deserting village could represent the ecological and social benefits, and more attention should be paid to evaluate the effectiveness of future studies and practices if the hollowing village indicates the socio-economic deficiency.

\subsection{The central town-village in mountainous areas proved to be the optimized mode}

It is still a big controversy which size of cities is best for human settlements from the economic and ecological perspectives. Some studies argued that small towns (cities) play a positive role in rural transformation development, and regard their roles as the "urban functions in rural development" (Belsky and Karaska, 1990; Li, 2012). Economists offered the criticism that small towns and cities do not comply with the law of economics and usually represent the inefficient use of resources, e.g., land use per person and energy consumption per capita. Some ecologists believe that small towns can achieve both environmental protection and meet human needs. Meanwhile, planners like Le Corbusier disagree and argue that urban dispersion and small town construction will be a disaster for ecological conservation. For instance, in China, due to the collective land ownership system and the pressures of economic growth, the local authorities change the agricultural land to urban land use in small towns, resulting in large cultivated area being occupied, thereby causing the out-of-balance social-ecological system (Corbusier, 1987; Deng et al., 2015).

In Shanghang County, $76.50 \%$ of the area is not suitable for the urban-rural settlements construction, whereas only $23.50 \%$ is. The suitable areas are distributed in the central and northeastern parts, as well as in the central town-villages and river valleys. Therefore, we suggested that urban-rural spatial restructuring should be based on this pattern. Meanwhile, we summarized the changing mode of rural settlements in Shanghang County, including the deserting village, central town-village, and city-oriented village (Figure 6). Additionally, using remote sensing images and spatial analysis of Shanghang County during 2004-2014, it was found that central town-villages' (where the township government is located) landscapes change more significantly than general settlements. Table 6 shows that the mean area of general settlements increased by 2.3 times, yet the mean area of the central town-villages increased by 4.59 times, and the mean value of perimeters of central town-village increased 250 times. All of these results support the hypothesis that central town-villages in mountainous area are key disturbance areas and it is also in line with the general law of development of mountainous urbanization (Zhang and Zhai, 2013). Meanwhile, through interviews and surveys with local authorities and residents, we concluded that the central town-village would play a positive role in urban-rural transformation and ecological conservation, as well as improve production and living conditions, and coordinate urban-rural development. In mountainous areas, the central town-villages and small cities would be the best means to unify human and nature as opposed to the situation characterized by sprawling cities (Fan $e t$ al., 2013). However, due to mountainous areas often being characterized by high biodiversity, rich cultural value, and ecological sensitivity, and as such being much harder to recover 
than other regions (Pôças et al., 2011), scientists and policymakers should pay more attention to evaluating environmental capacity and ecological thresholds in the process of urban-rural spatial restructuring and the central town-village construction.

To sum up, central town-villages experienced the most significant change in urban-rural settlement, and attract more and more people from "deserting villages." Therefore, some preferential policies and measures should be implemented in the future.

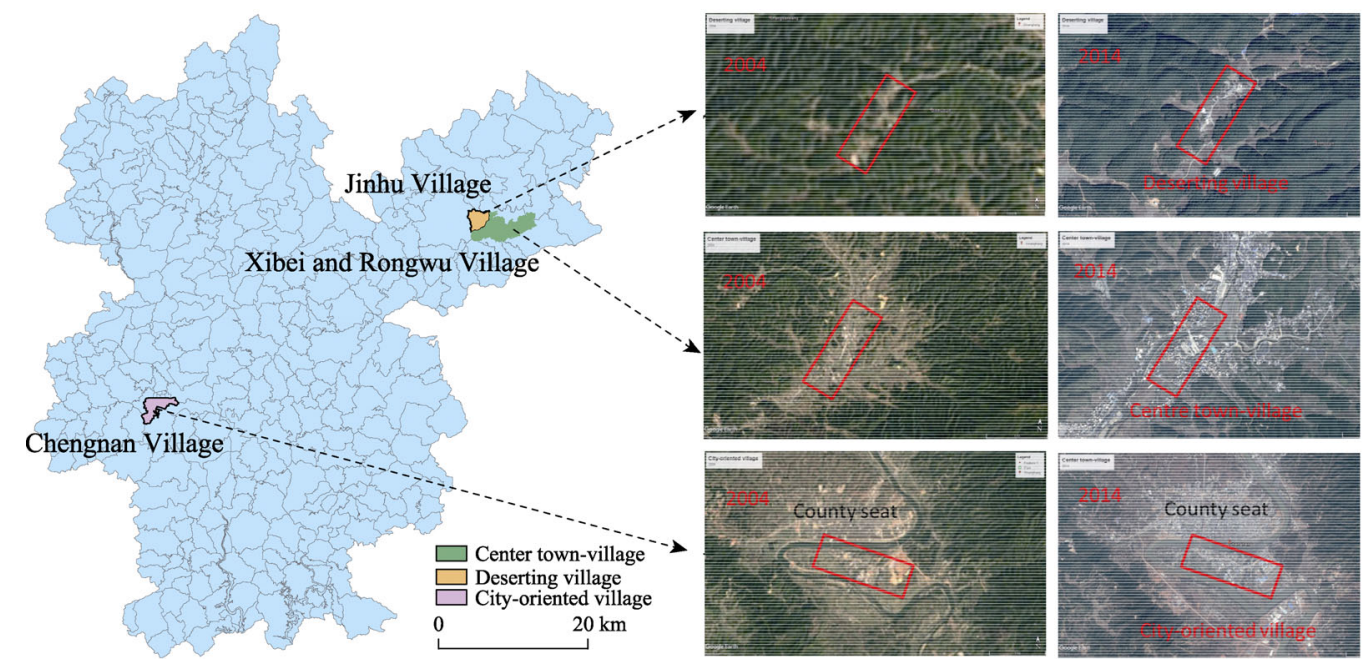

Figure 6 The images of three modes of change in rural settlements from the Google Earth

Table 6 Landscape metrics analysis of urban-rural settlements in 2004 and 2014

\begin{tabular}{ccccccc}
\hline Year & $\begin{array}{c}\text { Mean area of } \\
\text { general set- } \\
\text { tlement }\left(\mathrm{hm}^{2}\right)\end{array}$ & $\begin{array}{c}\text { Mean area of } \\
\text { center town- } \\
\text { village }\left(\mathrm{hm}^{2}\right)\end{array}$ & $\begin{array}{c}\text { Mean value of } \\
\text { perimeter of cen- } \\
\text { tral town-village } \\
(\mathrm{m})\end{array}$ & $\begin{array}{c}\text { Mean value of pe- } \\
\text { rimeter-area ratio of } \\
\text { central town-village }\end{array}$ & $\begin{array}{c}\text { Shape index } \\
\text { of central } \\
\text { town-village }\end{array}$ & AWMPFD \\
\hline 2004 & 4.88 & 60.15 & 2576.12 & 122.71 & 1.21 & 1.06 \\
2014 & 11.32 & 276.25 & 645080.18 & 74.01 & 1.54 & 1.07 \\
\hline
\end{tabular}

\section{Conclusions and suggestions}

So far, the process of industrialization and urbanization in China associated with greater globalization is continuing, accompanied by China's economy entering a new stage of development (so-called New Normal), as well as the "New Countryside" and "New-type Urbanization" strategies. In this context, urban-rural spatial restructuring and land consolidation have been embraced as the main strategy. Spatial problem-solving land management tools to alleviate the tension between urban-rural development and the needs of residents are needed to improve rural production and living conditions, and to coordinate urban-rural development. However, rural development and urbanization vary under different socio-geographic conditions, e.g., plain areas, coastal areas, and mountainous areas; or rural areas near the city compared to remote areas. Additionally, new legislation and regulations would also affect this process. For instance, total ownership of the rural land in China will be separated into land-use rights, contract rights, and operating rights. The consequences of these changes demand further investigation.

In this study, we mainly focused on mountainous areas, where rapid urbanization and 
dramatic changes in socio-economic conditions were experienced. To strengthen the scientific approach, we use the ecological niche model to quantify the urban-rural spatial restructuring in mountainous areas. We argue that this approach could be a valuable methodology in the conceptual model of rural spatial restructuring, as proposed by Long and Liu in 2016. In this case, the compound ecological niche model demonstrated that the most areas of Shanghang County are not suitable for urban-rural settlement construction. The areas that were highly inappropriate, slightly appropriate, moderately appropriate, and highly appropriate for urban-rural settlement construction were $1273.2 \mathrm{~km}^{2}(44.69 \%), 906.1 \mathrm{~km}^{2}$ (31.80\%), $509.4 \mathrm{~km}^{2}(17.88 \%)$, and $160.1 \mathrm{~km}^{2}(5.62 \%)$, respectively. Based on ecological niche analysis, we divided spatial restructuring and land consolidation into four types, which are the priority development, moderate development, limited development, and migrate-regulate areas. The percentages of the area for the four types of urban-rural settlements are $15.52 \%, 23.15 \%, 44.70 \%$, and $16.63 \%$, respectively. Some $61.33 \%$ of the settlements and $20.58 \%$ of the areas of settlements still need to be regulated. We also propose that, in contrast to the hollowing village in plain areas, the deserting village (vanishing evolutionary) in mountainous areas plays positive synergistic roles in urban-rural integrative development and urbanization, though both have the same driving forces and mechanisms. We also suggest that, if the hollowing village in the plain areas represents socio-economic deficiency, then the deserting village could be characterized by having ecological and social benefits. To balance ecological conservation, the improvement of production and living conditions, the cost of infrastructure investments, and coordination of the urban-rural development strategy, we argue that central town-villages will be the main settlements and more and more local residents who lived in deserting villages will move to them. Because mountainous areas normally have high ecological value and are ecologically sensitive, environmental capacity and ecological thresholds need to be taken into consideration in the central town-village construction process.

Urban-rural spatial restructuring and land consolidation, as well as the 'increasing vs. decreasing balance' land-use policy in mountainous areas, are indispensable ways to optimize the production, living, and ecological space on agriculture land and combat the deserting village effect and industrial and mining land consolidation. We hope that this study can add to regional geography and urbanization theory, as well as the hollowing village theory proposed by Liu and Long in 2015. We also hope this methodology and empirical study can apply to regional planning and land-use management.

\section{Additional information}

Supplementary information accompanies this paper online.

\section{References}

Antrop M, 2004. Landscape change and the urbanization process in Europe. Landscape and Urban Planning, 67(1-4): 9-26.

Bański J, Wesołowska M, 2010. Transformations in housing construction in rural areas of Poland's Lublin region: Influence on the spatial settlement structure and landscape aesthetics. Landscape and Urban Planning, 94(2): $116-126$.

Belsky E S, Karaska G J, 1990. Approaches to locating urban functions in developing rural areas. International Regional Science Review, 13(3): 225-240. 
Cao G, 1995. The definition of the niche by fuzzy set theory. Ecological Modelling, 77(1): 65-71.

Chisholm M, 1972. Rural Settlement and Land Use. Transaction Publishers.

Clark J K, McChesney R, Munroe D K et al., 2009. Spatial characteristics of exurban settlement pattern in the United States. Landscape and Urban Planning, 90(3): 178-188.

Corbusier L, 1987. The city of tomorrow and its planning. Courier Corporation.

Dai D, 2011. Racial/ethnic and socioeconomic disparities in urban green space accessibility: Where to intervene? Landscape and Urban Planning, 102(4): 234-244.

Deng X, Huang J, Rozelle S et al., 2015. Impact of urbanization on cultivated land changes in China. Land Use Policy, 45: 1-7.

Fan J, Wang Q, Zhou K, et al., 2013. Preliminary research on spatial pattern of urbanization in mountainous areas of China. City Planning Review, 5: 9-15. (in Chinese)

Forman R T, 2016. Urban ecology principles: Are urban ecology and natural area ecology really different? Landscape Ecology, 31(8): 1653-1662.

Hairston N G, Smith F E, Slobodkin L B, 1960. Community structure, population control, and competition. American Naturalist, 879: 421-425.

Han X, Huang Y, Hui C, 2015. Spatial distributions of niche-constructing populations. Computational Ecology and Software, 5(4): 286-298.

Hewitt K, 2014. Regions of Risk: A Geographical Introduction to Disasters. Routledge.

Kiss E, 2000. Rural restructuring in Hungary in the period of socio-economic transition. GeoJournal, 51(3): 221-233.

Li Y, 2012. Urban-rural interaction patterns and dynamic land use: Implications for urban-rural integration in China. Regional Environmental Change, 12(4): 803-812.

Li Z, Lin H, 1997. The niche-fitness model of crop population and its application. Ecological Modelling, 104(2): 199-203.

Liu J G, Ma S J, 1990. Expanded Ecological Niche: Modern Ecological Perspective. Beijing: Science Press. (in Chinese)

Liu Y S, Liu Y, Chen Y et al., 2010. The process and driving forces of rural hollowing in China under rapid urbanization. Journal of Geographical Sciences, 20(6): 876-888.

Liu Y S, Yang R, Li Y H, 2013. Potential of land consolidation of hollowed villages under different urbanization scenarios in China. Journal of Geographical Sciences, 23(3): 503-512.

Liu Y S, Zhang F, Zhang Y, 2009. Appraisal of typical rural development models during rapid urbanization in the eastern coastal region of China. Journal of Geographical Sciences, 19(5): 557-567.

Lo K, Xue L, Wang M, 2016. Spatial restructuring through poverty alleviation resettlement in rural China. Journal of Rural Studies, 47: 496-505.

Long H L, 2012. Land use transition and rural transformation development. Progress in Geography, 31(2): 131-138. (in Chinese)

Long H L, 2014. Land consolidation: An indispensable way of spatial restructuring in rural China. Journal of Geographical Sciences, 24(2): 211-225.

Long H L, Li Y, Liu Y et al., 2012. Accelerated restructuring in rural China fueled by 'increasing vs. decreasing balance' land-use policy for dealing with hollowed villages. Land Use Policy, 29(1): 11-22.

Long H L, Liu Y S, 2015. A brief background to rural restructuring in China: A forthcoming special issue of Journal of Rural Studies. Journal of Geographical Sciences, 25(10): 1279-1280.

Long H L, Liu Y S, 2016. Rural restructuring in China. Journal of Rural Studies, 47: 387-391.

Long H L, Tu S, Ge D et al., 2016. The allocation and management of critical resources in rural China under restructuring: Problems and prospects. Journal of Rural Studies, 47: 392-412.

Long H L, Zou J, Pykett J et al., 2011. Analysis of rural transformation development in China since the turn of the new millennium. Applied Geography, 31(3): 1094-1105.

Luo W, Whippo T, 2012. Variable catchment sizes for the two-step floating catchment area (2SFCA) method. Health \& place, 18(4): 789-795.

McGranahan G, Balk D, Anderson B, 2007. The rising tide: assessing the risks of climate change and human settlements in low elevation coastal zones. Environment and Urbanization, 19(1): 17-37.

Molden D, Hurni H, von Dach S W et al., 2015. Focus issue: Vulnerability and resilience to natural hazards and disasters in mountains. Mountain Research and Development, 35(2): 103-103.

Morrill R, Cromartie J, Hart G, 1999. Metropolitan, urban, and rural commuting areas: Toward a better depiction of the United States settlement system. Urban Geography, 20(8): 727-748.

Mubareka S, Ehrlich D, Bonn F et al., 2008. Settlement location and population density estimation in rugged terrain using information derived from Landsat ETM and SRTM data. International Journal of Remote Sensing, 29(8): 2339-2357.

Nie Y, Yu J, Cui C, 2012. Research on suitability evaluation of garden land in Yiling District based on GIS and niche-fitness model. Resources and Environment in the Yangtze Basin, 21(8): 1000-1005. (in Chinese) 
Odum E P, 1983. Basic Ecology. Saunders College Pub, Philadelphia.

Peng L, Liu S, Sun L, 2016. Spatial-temporal changes of rurality driven by urbanization and industrialization: A case study of the Three Gorges Reservoir Area in Chongqing, China. Habitat International, 51: $124-132$.

Pôças I, Cunha M, Marcal A R et al., 2011. An evaluation of changes in a mountainous rural landscape of Northeast Portugal using remotely sensed data. Landscape and Urban Planning, 101(3): 253-261.

Qin T T, Qi W, Li Y Q et al., 2012. Suitability evaluation of rural residential land based on niche theory in mountainous area. Acta Ecologica Sinica, 32(16): 5175-5183. (in Chinese)

Qu Y B, Zhang F R, Jiang G H et al., 2010. Suitability evaluation and subarea control and regulation of rural residential land based on niche. Transactions of the CSAE, 26(11): 290-296. (in Chinese)

Ren P, Hong B T, Liu Y et al., 2014. A study of spatial evolution characteristics of rural settlements and influences of landscape patterns on their distribution using GIS and RS. Acta Ecologica Sinica, 34(12): 3331-3340. (in Chinese)

Sevenant M, Antrop M, 2007. Settlement models, land use and visibility in rural landscapes: Two case studies in Greece. Landscape and Urban Planning, 80(4): 362-374.

Shelford V E, 1931. Some concepts of bioecology. Ecology, 12(3): 455-467.

Tan M, Li X, 2013. The changing settlements in rural areas under urban pressure in China: Patterns, driving forces and policy implications. Landscape and Urban Planning, 120: 170-177.

Unwin T, Nash B, 1992. Township boundaries: Theoretical considerations and analytical implications. The Transformation of the European Rural Landscape: Methodological Issues and Agrarian Change, 1914: $116-127$.

Wang C, Fei Z, Ye Q et al., 2014. Rural settlement space reconstruction strategy and implementation based on symbiosis theory on village scale. Transactions of the Chinese Society of Agricultural Engineering, 30(3): 205-214. (in Chinese)

Wang Y Y, Li Y B, Gan C H et al., 2013. Evolution of cultivated land in center region of the Three Gorges Reservoir Area based on terrain factors: A case study of Caotangxi watershed. Chinese Journal of Ecology, 32(7): 1903-1911. (in Chinese)

Webber B L, Le Maitre D C, Kriticos D J, 2012. Comment on "Climatic niche shifts are rare among terrestrial plant invaders". Science, 338(6104): 193-193.

Whittaker R H, Levin S A, Root R B, 1973. Niche, habitat, and ecotope. American Naturalist, 107(995): $321-338$.

Woods M, 2007. Engaging the global countryside: Globalization, hybridity and the reconstitution of rural place. Progress in Human Geography, 31(4): 485-507.

Woods M, 2013. Regions engaging globalization: A typology of regional responses in rural Europe. Journal of Rural and Community Development, 8(3): 113-126.

$\mathrm{Wu}$ F, 2002. Calibration of stochastic cellular automata: The application to rural-urban land conversions. International Journal of Geographical Information Science, 16(8): 795-818.

Xiao L S, Yu Z W, Ye H et al., 2015. The research of coupling rural development and economy cluster in Fujian province. Acta Geographica Sinica, 70(4): 615-624. (in Chinese)

Yang R, Xu Q, Long H, 2016. Spatial distribution characteristics and optimized reconstruction analysis of China's rural settlements during the process of rapid urbanization. Journal of Rural Studies, 47: 413-424.

Yao G, Xie H, 2016. Rural spatial restructuring in ecologically fragile mountainous areas of southern China: A case study of Changgang Town, Jiangxi Province. Journal of Rural Studies, 47: 435-448.

Yu Z W, Xiao L S, Guo Q H et al., 2016. Mountain county rural settlement landscape pattern change and spatial characteristics in rapid mountain urbanization process in Fujian province. Acta Ecologica Sininca, 36(10): 1-11. (in Chinese)

Zhang G M, Xie S C, 1997. Developement of niche concept and its perspectives: A review. Chinese Journal of Ecology, 16(6): 46-51. (in Chinese)

Zhang R, Jiang G, Wang M et al., 2015. Layout classification of rural settlement based on combination of multi-dimensional characteristics. Transactions of the Chinese Society of Agricultural Engineering, 31(4): 286-292. (in Chinese)

Zhang X Y, Zhai G F, 2013. Analysis of growth feature of spatial form for mountainous cities. Modern Urban Research, 2: 45-50, 56. (in Chinese)

Zhao J, Xu M, Lu S et al., 2013a. Human settlement evaluation in mountain areas based on remote sensing, GIS and ecological niche modeling. Journal of Mountain Science, 10(3): 378-387.

Zhao J, Zheng X, Dong R et al., 2013b. The planning, construction, and management toward sustainable cities in China needs the Environmental Internet of Things. International Journal of Sustainable Development \& World Ecology, 20(3): 195-198.

Zhou G, He Y, Tang C et al., 2013. Dynamic mechanism and present situation of rural settlement evolution in China. Journal of Geographical Sciences, 23(3): 513-524.

Zhu F, Zhang F, Li C et al., 2014. Functional transition of the rural settlement: Analysis of land-use differentiation in a transect of Beijing, China. Habitat International, 41: 262-271. 


\section{Appendix 1}

For urban-rural spatial restructuring of Shanghang County on a strategic level, based on our previous analysis, we proposed the "Arrow-type" spatial restructuring strategy.

To more clearly explain the reason why we proposed the "Arrow-type" urban-rural spatial restructuring strategy in Shanghang County (Figure 1). I would like to introduce the more specific background of Shanghang County.

- This strategy in line with the topographic condition. The south-north direction along the Tingjiang River, which is the valley area. For the northeast direction, the areas are also rather flat than other areas in Shanghang County.

- This strategy in line with the development planning of Shanghang County. In the northeast of Shanghang County, we plan to build a new development area.

- This strategy in line with the high-speed railway planning. A high-speed railway will go through Shanghang County; one railway station (Gutian station) is in the northeast of Shanghang.

We interviewed local authorities, urban planners, interest groups and local residents, as well as read many (planning and development) materials related to Shanghang County, Longyan City, and Fujian Province. Finally, on a strategy level, we proposed this "Arrow-type" spatial restructuring and development strategy.

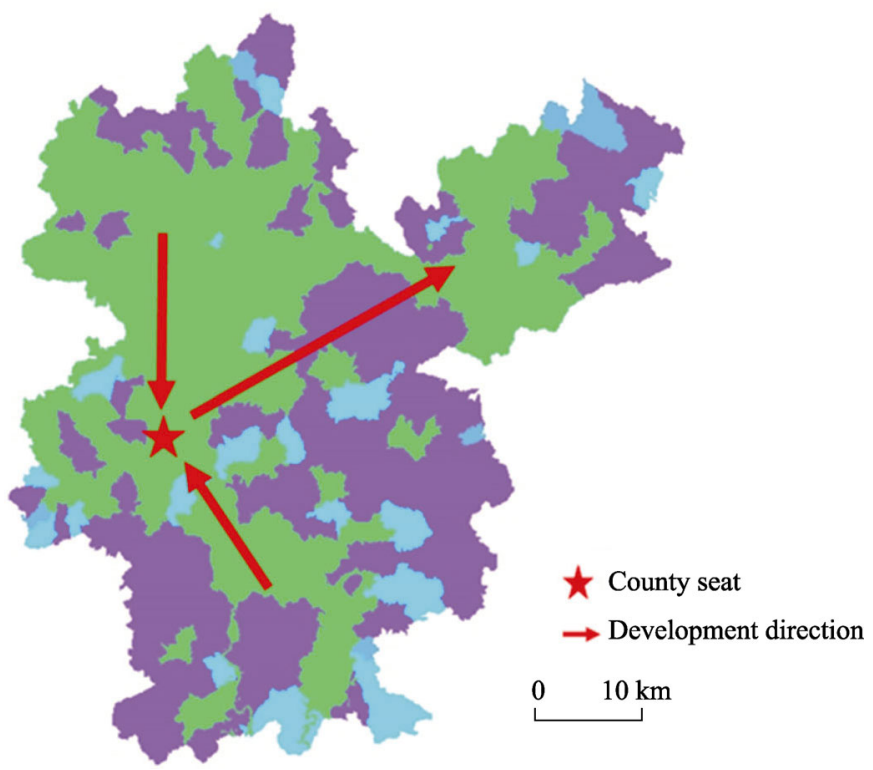

Figure 1 Urban-rural spatial restructuring and development direction in Shanghang County 